\title{
TP53 mutations, human papilloma virus DNA and inflammation markers in esophageal squamous cell carcinoma from the Rift Valley, a high- incidence area in Kenya
}

Kirtika Patel ${ }^{1}$, Simeon Mining ${ }^{1}$, Johnston Wakhisi ${ }^{1}$, Tarik Gheit ${ }^{2}$, Massimo Tommasino ${ }^{2}$, Ghislaine Martel-Planche ${ }^{3}$, Pierre Hainaut ${ }^{3}$ and Behnoush Abedi-Ardekani ${ }^{4,3^{*}}$

\begin{abstract}
Background: Squamous Cell Carcinoma of Esophagus is one of the most common malignancies in both men and women in eastern and south-eastern Africa. In Kenya, clinical observations suggest that this cancer is frequent in the Rift Valley area. However, so far, there has been no report on the molecular characteristics of esophageal squamous cell carcinoma (ESCC) in this area.

Results: We have analyzed TP53 mutations, the presence of human papilloma virus (HPV) DNA and expression of inflammation markers Cyclooxygenase 2 (Cox-2) and Nitrotyrosine (NTyR) in 28 cases (13 males and 15 females) of archived ESCC tissues collected at the Moi Teaching and Referral Hospital in Eldoret, Kenya. Eleven mutations were detected in TP53 exons 5 to 8 (39\%). All ESCC samples were negative for HPV 16, 18, 26, 31, 33, 35, 39, 45, 51, 52, $53,56,58,59,66,68,70,73$ and 82. Immunohistochemical analysis of Cox-2 and NTyR showed a low proportion of positive cases (17.4\% and 39.1\%, respectively). No association between the above markers and suspected risk factors (alcohol or tobacco use, hot tea drinking, use of charcoal for cooking) was found.

Conclusion: Our findings suggest that mechanisms of esophageal carcinogenesis in eastern Africa might be different from other parts of the world. Low prevalence of TP53 mutation compared with other intermediate or high incidence areas of the world highlights this hypothesis. Our data did not support a possible ole of HPV in this series of cases. Further studies are needed to assess and compare the molecular patterns of ESCC from Kenya with those of high-incidence areas such as China or Central Asia.
\end{abstract}

\section{Background}

Esophageal Squamous Cell Carcinoma (ESCC) is the $6^{\text {th }}$ most common cancer worldwide. About $80 \%$ of the cases occur in low and middle income countries, with large geographic variations in incidence [1]. The highest rates (over 50 per 100.000 person-years) are observed in areas of central Asia (in particular Northern Iran and central China). Intermediate incidence rates have been reported for parts of Latin America (Southern Brazil, Uruguay) and several regions in Europe (Western France, Hungary) [2]. The main risk factors in Western

\footnotetext{
* Correspondence: abedib@iarc.fr

${ }^{4}$ Digestive Disease Research Institute, Shariati Hospital, Tehran University of Medical Sciences, Tehran, Iran

Full list of author information is available at the end of the article
}

Countries include, combined consumption of tobacco and alcohol. In high incidence areas, a number of different factors such as hot tea consumption, low socio-economic status, low fresh fruit and vegetable intake and exposure to dietary carcinogens have been suggested to play a role [3-8]. The involvement of chronic infection by human papilloma viruses (HPV) is a controversial issue. Early results showing a high prevalence of HPV DNA in cases from high incidence areas of China $[9,10]$ have not been confirmed in more stringent, recent studies $[11,12]$.

ESCC has consistently been reported to be a frequent cancer in both males and females in southern and eastern Africa. In South Africa (Transkei region), molecular studies have reported a low prevalence of mutations in

\section{C) Biomed Central}


exons 5 to 8 of the TP53 tumor suppressor gene (17\%) [13-16], well below the world average (40\%) and the high prevalence observed in high incidence areas of China $(70 \%)[17,18]$ or Northern Iran $(90 \%)$ (AbediArdekani et al, not published). So far, there is no data on TP53 mutation prevalence in ESCC from other parts of Africa.

ESCC is a common cancer in some rural areas of Kenya [19]. In the Rift Valley, ESCC is the leading malignancy in males and the third after cervical and breast cancers in females $[20,21]$. A recent study in the Bomet District, Western Kenya, showed that ESCC accounted for 914 (34.6\%) of the 2643 cancers diagnosed between January 1999 and December 2007, with $6.3 \%$ of the patients less than 31 years [22].

We have performed a pilot study on 28 archived, paraffin embedded ESCC tissues from patients referring to the Moi Teaching and Referral Hospital (MTRH, Eldoret, Kenya). We have analysed TP53 mutations in exons 5 to 8, presence of high risk types of HPV, and Immunohistochemical (IHC) expression of two markers associated with inflammation damage (NTyR, a direct marker of protein damage by nitric oxide over expressed in ESCC linked with inflammation, $[23,24]$ and inflammatory response (Cox-2, which is often elevated in ESCC from various high-incidence areas, [25]).

\section{Methods}

\section{Patient selection}

Patients who underwent resection for primary ESCC at MTRH, Eldoret, Kenya, between June 2003 and July 2006 were recruited into the study. Diagnosis was performed at the histopathology department, MTRH, and confirmed at the International Agency for Research on Cancer (IARC). A group of 37 properly fixed and processed ESCC samples was assembled for further molecular studies. The patients were part of a case-control study with information on risk factors obtained through questionnaires at the time of diagnosis. All patients involved in that study had signed a written consent. (Patel K. et al., unpublished, manuscript in preparation). The study was approved by Ethics Review board of MTRH and of IARC.

\section{DNA extraction, TP53 mutation and HPV analysis}

DNA was extracted from areas of tissue sections containing over $50 \%$ of cancer cells as identified by a pathologist at IARC (B.A-A) using a column-based purification method. A total of 28 samples provided enough DNA of suitable quality for molecular analyses. TP53 mutations in exons 5-8 were analyzed using the IARC reference protocol http://www-p53.iarc.fr/Download/TP53_DirectSequencing_IARC.pdf. Samples were analysed by bidirectional sequencing and the analysis was repeated with two independent PCR products. Sequencing results were compared with the reference sequence X54156 from Genbank http:// p53.iarc.fr/TP53sequenceX54156.html. Sequence variations were checked with the mutation validation tool of the IARC TP53 mutation database http://www-p53.iarc.fr/ MutationValidationCriteria.asp.

HPV typing was performed as previously described [26]. Briefly, detection and typing of 19 mucosal high-risk HPV types (types 16, 18, 26, 31, 33, 35, 39, 45, 51, 52, 53, $56,58,59,66,68,70,73$, and 82 ) was performed by a combination of multiplex PCR and HPV type-specific primers for amplification of viral DNA (E7). PCR products were typed using arrayed primer extension (APEX). Amplification of Beta-globin was used as positive reaction control.

\section{Immunohistochemistry}

Among 28 cases, IHC study was possible on 23. Deparaffinised sections $(5 \mu \mathrm{M})$ were rehydrated and incubated with primary antibodies for either one hour at room temperature (DO7, mouse-anti p53 monoclonal antibody 1:500, Dako, Glostrup, Denmark), or overnight at $4^{\circ} \mathrm{C}$ (COX-2, polygoat, 1/2000, Santa Cruz Biotechnology) and NTyR (polyrabbit 1/2000, Upstate Biotechnology). Fixed antibodies were detected with secondary biotinylated anti-rabbit IgG (1/200, Vectasin Elite-ABC kit, Vector Laboratories Inc.) followed by streptavidinperoxidase and diaminobenzidine-based detection according to standard protocols (Vector Laboratories, Inc.) A score combining intensity of staining (0 to 3 ) and proportion of stained cancer cells $(0-10 \%: 0 ; 11$ 30\%: 1 ; 31-50\%: 2; over 50\%: 3) was used. The combined scores ranging from 0-9 were scored into 3 final groups: 0-3 (no to weak expression), 4-6 (moderate expression), and 7-9 (strong expression).

\section{Results}

The characteristics of the 28 patients analyzed for both TP53 mutations and HPV DNA are summarized in Table 1. This group comprised an approximately equal proportion of males and females, in agreement with the known gender distribution of ESCC in the population of the Rift Valley [21]. Age at diagnosis ranged from 23 to 72 years (average of 56 years) with no difference between genders. All cases were invasive carcinoma.

Among possible risk factors, tobacco was predominantly used as smoked product in males and as snuff in females. Alcohol drinking showed a strong bias towards men ( 9 males for 1 female). Exposure to charcoal fumes was almost restricted to women (11 of 12 exposed patients were women). Other factors, such as hot tea drinking, consumption of mursik (a local fermented milk product laced with charcoal) and poor oral hygiene (as documented by tooth loss) were equally distributed between genders. 


\begin{tabular}{|c|c|c|}
\hline \multicolumn{2}{|c|}{ Patient's characteristics, $\mathbf{n}=\mathbf{2 8}$} & \multirow{2}{*}{$\begin{array}{c}\text { Number } \\
13\end{array}$} \\
\hline Gender & Males & \\
\hline & Females & 15 \\
\hline \multirow[t]{2}{*}{ Age } & Average & $56.03 \pm 12.30$ \\
\hline & Range & $23-72$ \\
\hline \multirow[t]{3}{*}{ Tobacco use } & Smoking (ever; male/female) & $6 / 0$ \\
\hline & Snuff (ever; male/female) & $0 / 7$ \\
\hline & Any (ever/never) & $13 / 15$ \\
\hline Alcohol use & (ever; male/female) & $9 / 1$ \\
\hline Hot tea drinking* & (yes; male/female) & $6 / 11$ \\
\hline Consumption of Mursik & (yes; male/female) & $8 / 10$ \\
\hline Oral hygiene $^{+}$ & (poor; male/female) & $8 / 8$ \\
\hline Charcoal cooking & (yes; male/female) & $1 / 12$ \\
\hline
\end{tabular}

*: "hot" was considered as immediate drinking after pouring boiling tea

${ }^{+}:$Estimated on the basis of tooth loss

TP53 mutations (Table 2) were detected in 11 of 28 patients (39.3\%). None of these mutations occurred at common TP53 mutation hotspots as reported in the IARC TP53 database. Of the mutations, 6 were missense, 3 nonsense and 2 were deletions inducing frameshift and supposed to lead to premature termination of translation. Only one mutation was a transversion (A:T to T:A at codon 255, p.I255F). Among transition mutations, 3 were at CpG sites, all leading to nonsense substitutions.

Typing of 19 mucosal high-risk HPV types in the same DNA extracts as those used for TP53 mutation detection gave negative results (data not shown).

Immunohistochemical analysis on 23 cases (Figure 1 and Table 3) showed p53 protein accumulation (final groups of moderate and strong expression) in $18(78.2 \%)$ of the cases. Among 11 cases with TP53 mutations, IHC analysis was possible on 6 and 5 had moderate or strong p53 expression scores. NTyR and Cox-2 were absent or weakly expressed in, respectively, 14 (60.9\%) and 19 (82.6\%) of the cases, suggesting that expression of markers of inflammation was not a common characteristic of these ESCC cases.

\section{Discussion}

This study is the first report on the molecular characteristics of ESCC from patients of the Rift Valley, a possibly high incidence area in Eastern Africa. Although limited to 28 cases, this series is of interest since there is no report for ESCC in Africa except for a study in Transkei, South Africa [27]. In the present series, men and women were equally represented, a gender distribution similar to most high incidence areas where tobacco and alcohol are not the main risk factors for ESCC, such as in Northern Iran or in central China $[2,7,28]$. However, from a molecular viewpoint, ESCC from Rift Valley appears different from those high incidence areas in the prevalence of TP53 mutations. We report a prevalence of TP53 mutation of $39 \%$, far below the high prevalence reported in high incidence areas of China (50-75\%) [17,29-32], Northern Iran (90\%) (Abedi-Ardekani et al., not published) or Western France (Normandy, 76\%) [33]. Remarkably, a low prevalence of TP53 mutations has also been reported in Transkei [27]. Furthermore, the mutations identified, both in the present study and in Transkei, differ from the average mutation patterns of most cancers which are dominated by transition mutations at "hotspot" codons within CpG sites [34]. Although the small size of this study precludes any detailed analysis of mutation patterns, these results, together with those previously published for ESCC from Transkei, suggest that ESCC in south-eastern Africa may develop in a different mutagenic context than ESCC in other high-incidence areas. Of note, mutation analysis was limited to exons 5 to 8 since these exons contain about $90 \%$ of know mutations in ESCC and were the only exons previously analyzed in ESCC from Africa [27]. This choice was made necessary by the fact that only limited amounts of DNA was available from these formalin-fixed paraffin tissues.

Table 2 Characteristics of mutations in Esophageal Squamous Cell Carcinomas from Kenya

\begin{tabular}{|c|c|c|c|c|c|}
\hline Exon & Gene position & cDNA position & Codon and amino-acid change & Mutation & Mutation type \\
\hline 5 & g.12524A > G & $c .536 \mathrm{~A}>\mathrm{G}$ & p.H179R His-Arg & Missense & $A: T>G: C$ \\
\hline 6 & g.12706C > T & c. $637 \mathrm{C}>\mathrm{T}$ & p.R213X Arg-Stop & Nonsense & $\mathrm{G}: \mathrm{C}>\mathrm{A}: \mathrm{T}$ at $\mathrm{CpG}$ \\
\hline 6 & g.12706C > T & c. $637 \mathrm{C}>\mathrm{T}$ & p.R213X Arg-Stop & Nonsense & $\mathrm{G}: \mathrm{C}>\mathrm{A}: \mathrm{T}$ at $\mathrm{CpG}$ \\
\hline 7 & g.13386C > T & c. $749 \mathrm{C}>\mathrm{T}$ & p.P250L Pro-Leu & Missense & $G: C>A: T$ \\
\hline 7 & g.13400A > T & c. $763 \mathrm{~A}>\mathrm{T}$ & p.I255F Ile-Phe & Missense & $A: T>T: A$ \\
\hline 8 & g.13776G > A & c.796G > A & p.G266R Gly-Arg & Missense & $\mathrm{G}: \mathrm{C}>\mathrm{A}: \mathrm{T}$ \\
\hline 8 & g.13813C > T & $\mathrm{c} .833 \mathrm{C}>\mathrm{T}$ & p.P278L Pro-Leu & Missense & $\mathrm{G}: \mathrm{C}>\mathrm{A}: \mathrm{T}$ \\
\hline 8 & g.13816G > A & c. $836 \mathrm{G}>\mathrm{A}$ & p.G279E Gly-Glu & Missense & $\mathrm{G}: \mathrm{C}>\mathrm{A}: \mathrm{T}$ \\
\hline 8 & g.13896C > T & c.916C > T & p.R306X Arg-Stop & Nonsense & $\mathrm{G}: \mathrm{C}>\mathrm{A}: \mathrm{T}$ at $\mathrm{CpG}$ \\
\hline 8 & g.13811_13815del5 & c.831_835del5 & p.? & $F S^{*}$ & - \\
\hline 6 & g.12729_12732del4 & c.660_663del4 & p.? & FS & - \\
\hline
\end{tabular}



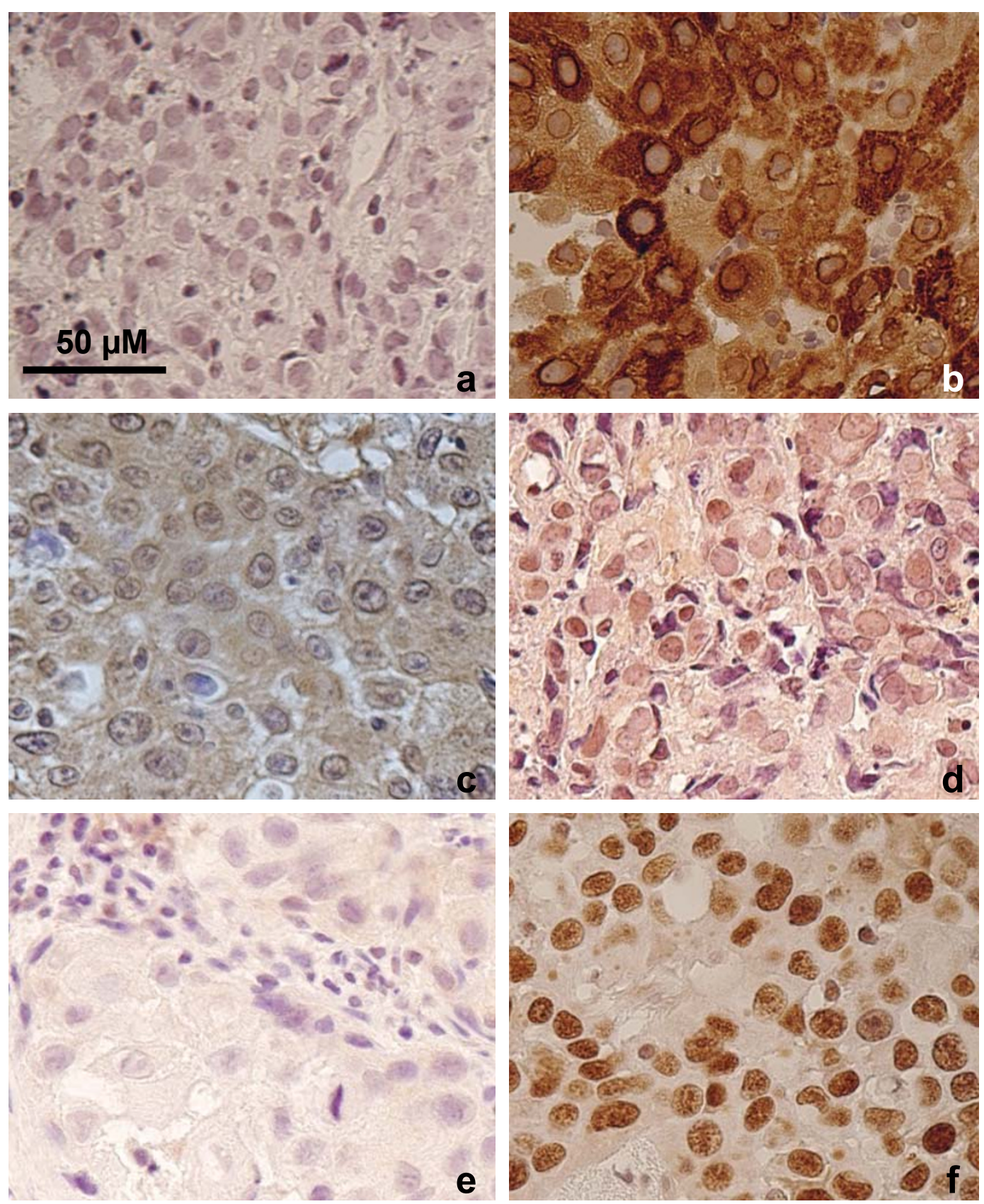

Figure 1 Detection of Cox-2, N-TyR and p53 proteins by immunohistochemistry in ESCC tissues $(\times 400)$. Typical examples of negative (left panels) or positive (right panels) staining are shown. (a-b): Cox-2; (c-d): N-TyR; (e-f): p53. Bar: scale in $\mu m$.

Low prevalence of TP53 mutations suggested that other molecular events may take place in ESCC from the Rift Valley. To address this hypothesis, we analyzed the presence of HPV DNA and the expression of markers of inflammation. High-risk HPV are known to contribute to carcinogenesis by inactivating the p53 protein in cervical and in oral cancers, thus bypassing the need for TP53 mutation $[35,36]$. Using a highly sensitive assay for high-

Table 3 Expression scores for p53, Cox-2 and NTyR in 23 cases of Esophageal Squamous Cell Carcinomas from Kenya

\begin{tabular}{cccc}
\hline Expression Score groups & p53 No. (\%) & Cox-2 No. (\%) & N-Tyrosine No. (\%) \\
\hline Absent or weak (0-3) & $5(21.8)$ & $19(82.6)$ & $14(60.9)$ \\
Moderate (4-6) & $9(39.1)$ & $3(13.0)$ & $5(21.7)$ \\
Strong (7-9) & $9(39.1)$ & $1(4.4)$ & $4(17.4)$ \\
\hline
\end{tabular}


risk HPV, we failed to detect any HPV sequences in the 28 cases tested. These results support the conclusions of a previous analysis performed on 29 biopsies of ESCC collected in the Bomet District, Western Kenya [37].

With respect to inflammation markers, only a small proportion of ESCC from the Rift Valley showed positive staining for either NTyR or Cox-2, two markers that we reported as highly expressed in ESCC from Iran (Tehran area) [23]. These results suggest that widespread inflammation is not a characteristic of ESCC in the Rift Valley. However, data on inflammation status of normal mucosa are needed to determine whether inflammatory conditions may play a role in the early steps of esophageal carcinogenesis.

\section{Conclusions}

The results presented here highlight that mechanisms of carcinogenesis in ESCC in eastern Africa may differ from other areas of the world. In particular, the low prevalence of TP53 mutation, also observed in ESCC from South Africa, suggests that some other mechanism of p53 inactivation may take place in these cancers. Our data do not support a role for HPV in this process. Furthermore, the risk factors associated with ESCC in Africa is poorly known. In South Africa, fumonisin, a mycotoxin that contaminates several components of the diet, have been proposed as significant risk factors [38,39]. Although fumonisins are present in the diet in east Africa [40], no study so far has addressed their potential role in the etiology of ESCC in the Rift Valley. If further studies with larger sample size and sequencing of all TP53 exons confirm our findings, then we may assume that the type of risk factors and/or mechanisms of carcinogenesis in ESCC in Eastern Africa are different from other highincidence areas of the world.

\section{Abbreviations \\ ESCC: esophageal squamous cell carcinoma; HPV: human papilloma virus; Cox-2: Cyclooxygenase 2; NTyR: Nitrotyrosine; MTRH: Moi teaching and referral hospital; IARC: international agency for research on cancer; IHC: immunohistochemistry.}

\section{Acknowledgements}

The authors are grateful to Ms C. Carreira, from the histopathology service lab at IARC, for immunohistochemistry.

\section{Author details \\ ${ }^{1}$ School of Medicine, Moi University, Eldoret, Kenya. ${ }^{2}$ Group of Infections and Cancer Biology, International Agency for Research on Cancer, Lyon, France. ${ }^{3}$ Group of Molecular Carcinogenesis, International Agency for Research on Cancer, Lyon, France. ${ }^{4}$ Digestive Disease Research Institute, Shariati Hospital, Tehran University of Medical Sciences, Tehran, Iran.}

\section{Authors' contributions}

KP, SM and JW participated in the study concept and provided the archived material. KP participated in the manuscript drafting. GM-P carried out the technical work of molecular analysis and sequencing. TG carried out the HPV DNA analysis. MT supervised the HPV analysis and participated in critical revision of the manuscript. PH was responsible for the study concept, design and supervision, manuscript drafting and critical revision. BA-A was responsible for pathology and immunohistochemistry evaluation, manuscript drafting and critical revision.

All authors read and approved the final manuscript.

\section{Competing interests}

The authors declare that they have no competing interests.

Received: 5 August 2011 Accepted: 31 October 2011

Published: 31 October 2011

\section{References}

1. Parkin DM, Bray F, Ferlay J, Pisani P: Global cancer statistics, 2002. CA Cancer J Clin 2005, 55:74-108.

2. Lambert R, Hainaut P: Esophageal cancer: cases and causes (part I). Endoscopy 2007, 39:550-555.

3. Abedi-Ardekani B, Kamangar F, Hewitt SM, Hainaut P, Sotoudeh M, Abnet CC, Taylor PR, Boffetta P, Malekzadeh R, Dawsey SM: Polycyclic aromatic hydrocarbon exposure in oesophageal tissue and risk of oesophageal squamous cell carcinoma in north-eastern Iran. Gut 2010, 59:1178-1183.

4. Abnet CC, Kamangar F, Islami F, Nasrollahzadeh D, Brennan P, Aghcheli K, Merat S, Pourshams A, Marjani HA, Ebadati A, Sotoudeh M, Boffetta P, Malekzadeh R, Dawsey SM: Tooth loss and lack of regular oral hygiene are associated with higher risk of esophageal squamous cell carcinoma. Cancer Epidemiol Biomarkers Prev 2008, 17:3062-3068.

5. Islami F, Kamangar F, Nasrollahzadeh D, Aghcheli K, Sotoudeh M, bediArdekani B, Merat S, Nasseri-Moghaddam S, Semnani S, Sepehr A, Wakefield J, Moller H, Abnet CC, Dawsey SM, Boffetta P, Malekzadeh R: Socio-economic status and oesophageal cancer: results from a population-based case-control study in a high-risk area. Int J Epidemiol 2009, 38:978-988.

6. Islami F, Pourshams A, Nasrollahzadeh D, Kamangar F, Fahimi S, Shakeri R, bedi-Ardekani B, Merat S, Vahedi H, Semnani S, Abnet CC, Brennan P, Moller H, Saidi F, Dawsey SM, Malekzadeh R, Boffetta P: Tea drinking habits and oesophageal cancer in a high risk area in northern Iran: population based case-control study. BMJ 2009, 338:b929.

7. Kamangar F, Malekzadeh R, Dawsey SM, Saidi F: Esophageal cancer in Northeastern Iran: a review. Arch Iran Med 2007, 10:70-82.

8. Nasrollahzadeh D, Kamangar F, Aghcheli K, Sotoudeh M, Islami F, Abnet CC, Shakeri R, Pourshams A, Marjani HA, Nouraie M, Khatibian M, Semnani S, Ye W, Boffetta P, Dawsey SM, Malekzadeh R: Opium, tobacco, and alcohol use in relation to oesophageal squamous cell carcinoma in a high-risk area of Iran. Br J Cancer 2008, 98:1857-1863.

9. Wang $X$, Tian $X$, Liu F, Zhao $Y$, Sun M, Chen D, Lu C, Wang Z, Shi X, Zhang Q, Zhang D, Shen Z, Li F, Harris CC, Cai H, Ke Y: Detection of HPV DNA in esophageal cancer specimens from different regions and ethnic groups: a descriptive study. BMC Cancer 2010, 10:19.

10. Chang F, Syrjanen S, Shen Q, Ji HX, Syrjanen K: Human papillomavirus (HPV) DNA in esophageal precancer lesions and squamous cell carcinomas from China. Int J Cancer 1990, 45:21-25.

11. Koshiol J, Wei WQ, Kreimer AR, Chen W, Gravitt P, Ren JS, Abnet CC, Wang JB, Kamangar F, Lin DM, von Knebel-Doeberitz M, Zhang Y, Viscidi R, Wang GQ, Gillison ML, Roth MJ, Dong ZW, Kim E, Taylor PR, Qiao YL, Dawsey SM: No role for human papillomavirus in esophageal squamous cell carcinoma in China. Int J Cancer 2010, 127:93-100.

12. de Villiers EM, Lavergne D, Chang F, Syrjanen $K$, Tosi P, Cintorino M, Santopietro R, Syrjanen S: An interlaboratory study to determine the presence of human papillomavirus DNA in esophageal carcinoma from China. Int J Cancer 1999, 81:225-228.

13. Sammon AM: Carcinogens and endemic squamous cancer of the oesophagus in Transkei, South Africa. Environmental initiation is the dominant factor; tobacco or other carcinogens of low potency or concentration are sufficient for carcinogenesis in the predisposed mucosa. Med Hypotheses 2007, 69:125-131.

14. Matsha T, Brink L, van RS, Hon D, Lombard C, Erasmus R: Traditional homebrewed beer consumption and iron status in patients with esophageal cancer and healthy control subjects from Transkei, South Africa. Nutr Cancer 2006, 56:67-73.

15. Sammon AM, Iputo JE: Maize meal predisposes to endemic squamous cancer of the oesophagus in Africa: breakdown of esterified linoleic acid 
to the free form in stored meal leads to increased intragastric PGE2 production and a low-acid reflux. Med Hypotheses 2006, 67:1431-1436.

16. Hendricks D, Parker MI: Oesophageal cancer in Africa. IUBMB Life 2002, 53:263-268.

17. Bennett WP, von Brevern MC, Zhu SM, Bartsch H, Muehlbauer KR, Hollstein MC: p53 mutations in esophageal tumors from a high incidence area of China in relation to patient diet and smoking history. Cancer Epidemiol Biomarkers Prev 1997, 6:963-966.

18. Lam KY, Tsao SW, Zhang D, Law S, He D, Ma L, Wong J: Prevalence and predictive value of p53 mutation in patients with oesophageal squamous cell carcinomas: a prospective clinico-pathological study and survival analysis of 70 patients. Int J Cancer 1997, 74:212-219.

19. White RE, Abnet CC, Mungatana CK, Dawsey SM: Oesophageal cancer: a common malignancy in young people of Bomet District, Kenya. Lancet 2002, 360:462-463

20. Tenge CN, Kuremu RT, Buziba NG, Patel K, Were PA: Burden and pattern of cancer in Western Kenya. East Afr Med J 2009, 86:7-10.

21. Wakhisi J, Patel K, Buziba N, Rotich J: Esophageal cancer in north rift valley of Western Kenya. Afr Health Sci 2005, 5:157-163.

22. Parker RK, Dawsey SM, Abnet CC, White RE: Frequent occurrence of esophageal cancer in young people in western Kenya. Dis Esophagus 2010, 23:128-135.

23. Sepehr A, Taniere P, Martel-Planche G, Zia'ee AA, Rastgar-Jazii F, Yazdanbod M, Etemad-Moghadam G, Kamangar F, Saidi F, Hainaut P: Distinct pattern of TP53 mutations in squamous cell carcinoma of the esophagus in Iran. Oncogene 2001, 20:7368-7374.

24. Vaninetti NM, Geldenhuys L, Porter GA, Risch H, Hainaut P, Guernsey DL, Casson AG: Inducible nitric oxide synthase, nitrotyrosine and p53 mutations in the molecular pathogenesis of Barrett's esophagus and esophageal adenocarcinoma. Mol Carcinog 2008, 47:275-285.

25. de Moraes E, Dar NA, de Moura Gallo CV, Hainaut P: Cross-talks between cyclooxygenase-2 and tumor suppressor protein p53: Balancing life and death during inflammatory stress and carcinogenesis. Int J Cancer 2007, 121:929-937.

26. Gheit T, Landi S, Gemignani F, Snijders PJ, Vaccarella S, Franceschi S, Canzian $\mathrm{F}$, Tommasino M: Development of a sensitive and specific assay combining multiplex PCR and DNA microarray primer extension to detect high-risk mucosal human papillomavirus types. J Clin Microbiol 2006, 44:2025-2031.

27. Gamieldien W, Victor TC, Mugwanya D, Stepien A, Gelderblom WC, Marasas WF, Geiger DH, van Helden PD: p53 and p16/CDKN2 gene mutations in esophageal tumors from a high-incidence area in South Africa. Int J Cancer 1998, 78:544-549.

28. Islami F, Kamangar F, Aghcheli K, Fahimi S, Semnani S, Taghavi N, Marjani HA, Merat S, Nasseri-Moghaddam S, Pourshams A, Nouraie M, Khatibian M, Abedi B, Brazandeh MH, Ghaziani R, Sotoudeh M, Dawsey SM, Abnet CC, Taylor PR, Malekzadeh R: Epidemiologic features of upper gastrointestinal tract cancers in Northeastern Iran. Br J Cancer 2004, 90:1402-1406

29. Cao W, Chen X, Dai H, Wang H, Shen B, Chu D, McAfee T, Zhang ZF: Mutational spectra of p53 in geographically localized esophageal squamous cell carcinoma groups in China. Cancer 2004, 101:834-844.

30. Gao H, Wang LD, Zhou Q, Hong JY, Huang TY, Yang CS: p53 tumor suppressor gene mutation in early esophageal precancerous lesions and carcinoma among high-risk populations in Henan, China. Cancer Res 1994, 54:4342-4346.

31. Hu N, Huang J, Emmert-Buck MR, Tang ZZ, Roth MJ, Wang C, Dawsey SM, Li G, Li WJ, Wang QH, Han XY, Ding T, Giffen C, Goldstein AM, Taylor PR: Frequent inactivation of the TP53 gene in esophageal squamous cell carcinoma from a high-risk population in China. Clin Cancer Res 2001, 7:883-891

32. Lung ML, Chan WC, Zong YS, Tang CM, Fok CL, Wong KT, Chan LK, Lau KW: p53 mutational spectrum of esophageal carcinomas from five different geographical locales in China. Cancer Epidemiol Biomarkers Prev 1996, 5:277-284.

33. Breton J, Sichel F, Abbas A, Marnay J, Arsene D, Lechevrel M: Simultaneous use of DGGE and DHPLC to screen TP53 mutations in cancers of the esophagus and cardia from a European high incidence area (Lower Normandy, France). Mutagenesis 2003, 18:299-306.

34. Petitjean A, Mathe E, Kato S, Ishioka C, Tavtigian SV, Hainaut P, Olivier M Impact of mutant p53 functional properties on TP53 mutation patterns and tumor phenotype: lessons from recent developments in the IARC TP53 database. Hum Mutat 2007, 28:622-629.

35. Kreimer AR, Clifford GM, Boyle P, Franceschi S: Human papillomavirus types in head and neck squamous cell carcinomas worldwide: a systematic review. Cancer Epidemiol Biomarkers Prev 2005, 14:467-475.

36. Moody CA, Laimins LA: Human papillomavirus oncoproteins: pathways to transformation. Nat Rev Cancer 2010, 10:550-560.

37. White RE, Mungatana C, Mutuma G, Robert ME, Daniel RW, Topazian MD, Shah KV: Absence of human papillomavirus in esophageal carcinomas from southwestern Kenya. Dis Esophagus 2005, 18:28-30.

38. van der WL, Shephard GS, Rheeder JP, Burger HM, Gelderblom WC, Wild CP, Gong YY: Simple intervention method to reduce fumonisin exposure in a subsistence maize-farming community in South Africa. Food Addit Contam Part A Chem Anal Control Expo Risk Assess 2010, 27:1582-1588.

39. Wild CP, Gong YY: Mycotoxins and human disease: a largely ignored global health issue. Carcinogenesis 2010, 31:71-82.

40. Kedera CJ, Plattner RD, Desjardins AE: Incidence of Fusarium spp. and levels of fumonisin B1 in maize in western Kenya. Appl Environ Microbiol 1999, 65:41-44

doi:10.1186/1756-0500-4-469

Cite this article as: Patel et al: TP53 mutations, human papilloma virus DNA and inflammation markers in esophageal squamous cell carcinoma from the Rift Valley, a high-incidence area in Kenya. BMC Research Notes 2011 4:469.

\section{Submit your next manuscript to BioMed Central and take full advantage of:}

- Convenient online submission

- Thorough peer review

- No space constraints or color figure charges

- Immediate publication on acceptance

- Inclusion in PubMed, CAS, Scopus and Google Scholar

- Research which is freely available for redistribution

Submit your manuscript at www.biomedcentral.com/submit
C BioMed Central 